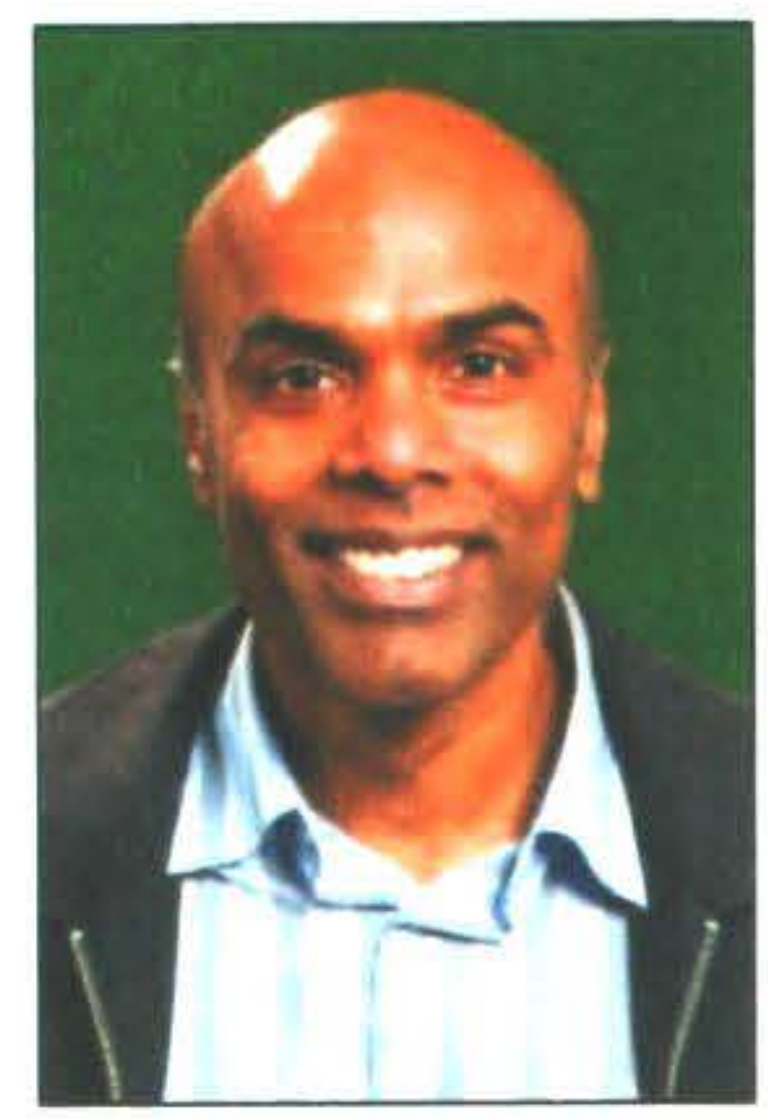

\title{
NET RETURNS FOR SEASONAL \\ WORKERS BASED ON A LIMITED \\ DEPARTMENT OF LABOUR (DOL) \\ AUDIT OF WAGES, HOURS AND \\ COSTS/DEDUCTIONS
}

\author{
Sankar Ramasamy \\ Department of Labour
}

\begin{abstract}
Do workers financially gain by coming to New Zealand under the Recognised Seasonal Employer (RSE) policy? This question among others attracted wide attention when the policy completed one year since implementation. Given that workers from the kick Start Pacific states work in a range of work settings, the Department of Labour undertook a sample audit of RSE employers during mid-2008. The audit was considered a cost-effective method to provide reliable estimates of what workers potentially earned and their likely net returns after costs and deductions. The results showed that on average workers had a net return of around NZ\$6,000. This is early indicative evidence and note that the audit primarily covered a part of the year when the weather and work availability was more settled.
\end{abstract}

\section{Introduction}

Recognized Seasonal Employer (RSE) policy is an innovative international migration policy that explicitly attempts to achieve the triple wins for migrants and their countries of origin and destination (Ramasamy et al, 2008). This policy which highlights the role of migration and development emerged from a tripartite negotiation between New Zealand government, industry and the Pacific states and came into effect in April 2007.

On the one hand, the RSE policy as a fulcrum for the Seasonal Labour Strategy aims to alleviate the problem of seasonal labour shortages in New Zealand's horticulture and viticulture industries and bring transformative changes within these industries. On the other hand, it provides labour mobility options for people from Pacific Forum countries and contributes to development outcomes for the sending countries and the region.

To ensure success and meet policy objectives in the longer-term, the RSE policy needs to provide sustainable benefits for workers, Pacific states, employers, and industry while preserving employment opportunities for New Zealanders. Fundamental to assessing these intended policy outcomes is gaining an understanding of how the policy benefits workers and employers in the short term and whether the costs of participating in this programme are outweighed by the benefits for both groups. One of the key outcomes for Pacific states' public service agencies relate to enabling their citizens to generate savings and acquire relevant experience.

This paper attempts to provide limited and preliminary evidence relating to workers earnings and savings. More specifically the paper aims to describe the potential net returns for workers coming to New Zealand under the RSE policy and provide indications on whether participation is economically viable for these workers. Earnings and savings is one key outcome for workers among several others.

\section{Background}

\section{Policy Requirements}

The RSE policy is designed to be facilitative for industry, ensure New Zealanders are given first opportunity for employment, manage immigration risk, and help increase labour productivity. A key element of the policy is to ensure there is a cost wedge between employing New Zealanders and accessing RSE workers (Government of New Zealand, 2006). As part of the Agreement to Recruit $(\mathrm{ATR})^{1}$ workers application, employers will also undertake specific responsibilities relating to their potential employees, including:

- a commitment to pay one half of the travel costs for the workers to fly to and from New Zealand

- a guarantee of wages for at least 240 hours of work, or an appropriate amount if the employment agreement is for less than 240 hours (i.e. for shortterm engagements)

- a guarantee of an average of at least 30 hours work per week

- $\quad$ evidence of specific provisions to address pastoral care matters (including accommodation, translation, transportation and induction to life in New Zealand, including providing opportunities for recreation and religious observance where appropriate)

- $\quad$ evidence that employees will be paid at least New Zealand market rates

- a commitment to pay for the costs associated with removal from New Zealand if workers become illegal and are deported, and 
While imposing a cost wedge for employers, the policy provisions are intended to make it economically worthwhile for workers in that the costs do not dilute the development benefits. Therefore workers from the Kick Start states are allowed to stay up to seven months within any 11-month period. In December 2007, Cabinet agreed to an interim policy amendment to allow employers recruiting from Kiribati and Tuvalu to pay half the airfare from Fiji to New Zealand instead of the entire airfare form Tuvalu and Kiribati. To offset these costs, Cabinet agreed that those from Tuvalu and Kiribati may work in New Zealand for nine months instead of seven within the 11-month period.

Besides the above policy provisions, RSE workers are covered by prevailing employment standards that New Zealanders enjoy. The labour inspectors are responsible for assisting employers (including contractors) to meet employment relations standards, monitoring and reporting on workplace conditions and health and safety issues ${ }^{2}$. The RSE Labour Inspector has a role in ensuring that the provisions of Employment and Health and Safety based legislation have been met. There are various Acts of Parliament that have application to the RSE workplace and the main Acts (Holidays Act 2003 etc) and best practice devised by the labour inspectorate are summarised in Appendix A.

\section{Progressive Reviews}

Since the beginning of the year the RSE policy had been under public scrutiny with mixed accounts of worker and employer experiences of the policy. Some were positive in finding that the general sense in the industry and in the government agencies responsible that the policy was working reasonably well (Courtney, 2008). In Vanuatu John Hammond and John Connell reported that 'there have at least been clear income gains, though it is not yet possible to indicate what these have been used for, but they appear to be focused on a development agenda' (2008:14). One report that what the seasonal workers earned in New Zealand net of expenses in the less than one year they spent there was more than what they would have earned back in their home nations. For a nation like Vanuatu, which unlike other Pacific Islands has no remittance revenue channel to speak of, the RSE policy was expected to have opened a whole new opportunity, earning for the economy as much as 55 million Vatu (equivalent to approximately $\mathrm{A} \$ 670,500$ ) in the first year alone $^{3}$.

Some reports acknowledged the overall success but also raised questions over the working of aspects of the scheme. Poor housing, lack of work at down times, contracts being set by piece rate at minimum wage rather than market rates and workers not being fully informed of deductions were some of the issues highlighted in a study by Nic Mcllelan (2008).

Against this general background of mixed messages, the

Department was required to collect information on the actual living and work conditions for RSE workers. This was achieved through an audit exercise of pastoral care and work conditions undertaken by RSE labour inspectors. This audit provided the information and data for this paper.

\section{How did the audit fit into the evaluation strategy?}

The Department's evaluation strategy for RSE comprises three internal strands - monitoring of key activities and outcomes, real-time evaluation feedback loops to augment operational activities to refine RSE processes and activities over time and formal evaluation study of aspects of RSE policy ${ }^{4}$. The Department through its external research partners' - Waikato University and The World Bank - supports the evaluation of development outcomes for the participating Pacific states. The formal evaluation forms the core with the other strands both internal and external informing this.

Labour inspectors as indicated earlier are tasked with assessing employers' compliance with RSE policy, which includes the employment and training of New Zealanders, payment of market rates and provision of pastoral care. They are expected to be involved in a three-stage audit cycle for every RSE employer from the time of accreditation on through to completing the period of employment specified in an Agreement to Recruit. This inbuilt reporting and audit function provided evaluation with an opportunity to gather information around pastoral care and work conditions. Consolidating monitoring data from existing operations has meant efficient sharing of available information resources across the Department and to provide a shared understanding of emerging issues for policy and delivery to address in a timely manner.

\section{Methodology}

The information gathered included the audit of pastoral conditions for all RSE employers that had workers in New Zealand at the time (phase 1) and an audit of wages, hours, costs and or deductions (phase 2). This study is based on data collected from phase 2 involving 17 RSE employers. The first iteration of phase 2 had covered 12 RSE employers. The analysis results for 12 and 17 RSE employers do not change much but the increased numbers mean the range varies more and there is a better understanding of the distribution of wages, hours, costs and deductions.

\section{Sample}

An entire audit of all wage records by labour inspectors would have involved physically inspecting 70,000 records. Given the enormity of this task, the agreed approach was to obtain a sample of some RSE employers according to the following criteria:

- $\quad$ Select a single ATR for each RSE employer 
ATRs with at least 30 workers where possible.

The ATR duration had been between Sept 07 and June 08

- Workers had completed the season and returned

- A range of regions and RSE employer types covered

- Based on the above criteria, IMSED Research ${ }^{5}$ provided a sample of 18 RSE employers across 8 regions for auditing.

There were only 6 RSE employers who had 30 or more workers for the ATR's identified. Where workers per ATR were more than 30 , the selection rule was to randomly sample $50 \%$ or 30 workers whichever number was greater. This was achieved in almost all cases. Only one RSE among the 18 identified could not be audited and a final audit of 402 individual worker records were completed (Refer Appendix B).

During the RSE year 2007-08 (April 2007 - March 2008) the total number of RSE workers approved for work was 3622. Of these 2646 were from the five Kick Start states of Vanuatu, Tonga, Samoa, Kiribati and Tuvalu ${ }^{6}$ and the majority from the first three states. A sample of 402 meant that that a substantial number of workers in the population of interest in the Kick Start States were covered.

The 17 RSE employers who took part in the audit were largely employers of seasonal labour from Samoa, Tonga and Vanuatu. It is reasonable to assume that the income opportunities and costs for the 407 workers covered by the audit are generally the same for workers from other Pacific states as well.

\section{Calculation of net returns}

The calculation of net returns attempted in this study does not present a fine grained picture of net returns. Net income depends on a number of factors such as: Length of time, availability of worker during that time, productivity of worker, morale of group of workers and their ability to adapt and settle down, standard of pastoral care, variability in workers' fixed and variable costs.

Net returns $/$ Balance $=($ Gross pay + Tax credit + Holiday pay) - (PAYE + one off deductions (e.g. clothing, passport) \& weekly deductions (e.g. food, transport). What this does not include is: a) complete upfront costs unless accounted for in weekly deductions and b) additional expenditure incurred in day-to-day living, purchase of consumer goods or capital items.

The audit covered wages, hours and deductions and costs. However calculation of deductions is problematic for the following reasons: sometimes it is not known if payment is set up to come from worker account or in fact the expense is directly managed by the workers (e.g. food, transport). Workers may be told the gross rates of pay, but not fully informed of all deductions by employers to cover housing, transport costs or recouping airfares. Therefore, this analysis focuses more on using the recorded wages and using a combination of actual deductions or assumed costs based on phase 1 audit of pastoral care, to arrive at balance left or net returns, rather than on estimating levels of average deductions on a weekly basis.

The information on wages does not distinguish between piece rates and hourly rates.

\section{Key findings}

The analysis is split into two parts. The first part is based on analysis of the 17 RSEs audited while the second part is based on 402 individual workers (across the 17 RSEs)? As information was coded differently and in some cases missing data replaced with imputed values, for the first part it is easier to base the analysis across the RSEs. However, a cross-check of results using RSE and individual worker records in parts 1 and 2 revealed there is not much difference.

\section{Part 1 - Analysis of averages across the 17 RSEs}

Table 1: Average weeks and hours worked

\begin{tabular}{lcccc}
\hline RSE type & No of workers & Period of work & AVG Weeks & AVG hours worked \\
\hline Grower 8 & 10 & Apr 08 - Jul 08 & 12.00 & 549.37 \\
Grower 12 & 22 & Mar 08 - May 08 & 9.00 & 462.19 \\
Grower/packhouse 1 & 16 & Apr 08 - Jun 08 & 11.00 & 506.06 \\
Grower 11 & 23 & Feb 08 - May 08 & 10.00 & 383.30 \\
Grower/packer 1 & 20 & Feb 08 - May 08 & 12.00 & 570.51 \\
Grower 4 & 22 & Feb 08 - Apr 08 & 9.94 & 417.86 \\
Grower 3 & 22 & Feb 08 - May 08 & 11.42 & 445.09 \\
Grower 6 & 15 & Feb 08 - Jun 08 & 15.70 & 674.80 \\
Grower 5 & 15 & Jan 08 - Apr 08 & 15.57 & 609.73 \\
Grower 2 & 23 & Sept 07 - Jan 08 & 15.14 & 726.86 \\
Grower 10 & 30 & Nov 07 - Jun 08 & 21.22 & n.a \\
Contractor 1 & 19 & Sept 07 - Jun 08 & 19.00 & 691.09 \\
Grower 13 & 30 & Dec 07 - Apr 08 & 21.00 & 786.50 \\
Grower 9 & 30 & Nov 07 - May 08 & 22.98 & n.a \\
Cooperative 1 & 50 & Oct 07 - May 08 & 27.36 & 1141.02 \\
Grower 1 & 20 & Oct 07 - Apr 08 & 28.55 & 1009.34 \\
Grower 7 & 35 & Nov 07 - May 08 & 26.30 & 1493.64 \\
Un-weighted AVERAGE & 402 & 16.95 & 697.82 \\
\hline Weighted AVERAGE & $\mathbf{4 0 2}$ & & $\mathbf{1 8 . 4 8}$ & $\mathbf{6 5 9 . 6 9}$ \\
\hline
\end{tabular}


Workers were employed for period of at least 9 weeks, with the maximum length of employment of over 28 weeks. The average number of hours worked was dependent on the employment period and has an average of almost 660 . Most workers number of working hours was close to the average however some (those employed for a longer number of weeks) worked for over 1000 hours with a maximum of 1493 .

Table 2: Average deductions and costs

\begin{tabular}{|c|c|c|c|c|c|c|}
\hline \multirow[t]{2}{*}{ RSE type } & \multirow{2}{*}{$\begin{array}{c}\begin{array}{c}\text { One-off fixed } \\
\text { costs }\end{array} \\
\text { AVG one-off } \\
\text { Airfare } \\
\text { payment by } \\
\text { worker }\end{array}$} & \multicolumn{5}{|c|}{ Weekly costs/deductions } \\
\hline & & $\begin{array}{c}\text { AVG weekly } \\
\text { Accommodation }\end{array}$ & $\begin{array}{l}\text { AVG weekly } \\
\text { Food }\end{array}$ & $\begin{array}{l}\text { AVG weekly } \\
\text { Transport to } \\
\text { and from work }\end{array}$ & $\begin{array}{c}\text { AVG weekly } \\
\text { Health } \\
\text { insurance }\end{array}$ & $\begin{array}{c}\text { AVG Weekly } \\
\text { Total }\end{array}$ \\
\hline Contractor 1 & $\$ 249$ & $\$ 118$ & $\$ 41$ & $\$ 22$ & $\$ 12$ & $\$ 192$ \\
\hline Grower 9 & $\$ 393$ & $\$ 95$ & $\$ 40$ & $\$ 42$ & $\$ 0$ & $\$ 177$ \\
\hline Grower 13 & $\$ 400$ & $\$ 100$ & $\$ 36$ & \$o & $\$ 11$ & $\$ 147$ \\
\hline Grower 1 & $\$ 368$ & $\$ 110$ & $\$ 41$ & $\$ 10$ & $\$ 0$ & $\$ 161$ \\
\hline Grower 8 & $\$ 1,091$ & $\$ 100$ & $\$ 50$ & \$0 & $\$ 11$ & $\$ 161$ \\
\hline Grower 4 & $\$ 298$ & $\$ 100$ & $\$ 41$ & $\$ 0$ & $\$ 11$ & $\$ 152$ \\
\hline Grower 11 & $\$ 470$ & $\$ 100$ & $\$ 55$ & $\$ 9$ & $\$ 11$ & $\$ 175$ \\
\hline Grower 5 & $\$ 672$ & $\$ 113$ & $\$ 41$ & $\$ 22$ & $\$ 11$ & $\$ 186$ \\
\hline Grower 12 & $\$ 391$ & $\$ 110$ & $\$ 41$ & $\$ 0$ & $\$ 9$ & $\$ 160$ \\
\hline Grower/packhouse 1 & $\$ 413$ & $\$ 47$ & $\$ 41$ & $\$ 55$ & $\$ 11$ & $\$ 154$ \\
\hline Grower 2 & $\$ 467$ & $\$ 85$ & $\$ 10$ & $\$ 26$ & $\$ 11$ & $\$ 131$ \\
\hline Grower 7 & $\$ 0$ & $\$ 60$ & $\$ 54$ & $\$ 17$ & $\$ 0$ & $\$ 131$ \\
\hline Grower 10 & $\$ 201$ & $\$ 80$ & $\$ 41$ & $\$ 5$ & $\$ 11$ & $\$ 137$ \\
\hline Grower 3 & $\$ 77$ & $\$ 89$ & $\$ 41$ & $\$ 0$ & $\$ 9$ & $\$ 139$ \\
\hline Grower 6 & $\$ 1,330$ & $\$ 82$ & $\$ 41$ & $\$ 0$ & $\$ 11$ & $\$ 134$ \\
\hline Grower/packer 1 & $\$ 225$ & $\$ 100$ & $\$ 41$ & $\$ 0$ & $\$ 6$ & $\$ 147$ \\
\hline Cooperative 1 & $\$ 426$ & $\$ 70$ & $\$ 41$ & $\$ 0$ & $\$ 0$ & $\$ 111$ \\
\hline Un-weighted average & $\$ 439$ & $\$ 92$ & $\$ 41$ & $\$ 23$ & $\$ 10$ & $\$ 153$ \\
\hline
\end{tabular}

- \$41 was imputed based on average cost estimated from phase 1 audit.

** $\$ 0$ indicates no transport costs were incurred (e.g. workplace adjacent to accommodation) or no health insurance was paid.

The cost of airfare showed considerable variation depending on the distance traveled from the source country. The weekly accommodation was less variable with 14 of the 17 worker groups falling between $\$ 80$ and $\$ 118$ per week. The remaining three were cheaper with the lowest cost being $\$ 47$. The average weekly amount spent on food also showed little variation, with the majority of workers spending the average of $\$ 41$ per week $^{8}$. Workers also spent an average of $\$ 23$ per week on transport to and from work. The cost of health insurance was dependent on whether the worker had been provided access to health insurance. The average cost was $\$ 10$ per week, although the majority of those who had insurance paid $\$ 11$ per week.

Table 3: Average pay and taxes of workers

\begin{tabular}{lccc}
\hline \multicolumn{1}{c}{ RSE type } & AVG Gross Pay & AVG Holiday pay & AVG PAYE \\
\hline Grower 8 & $\$ 6,980$ & $\$ 558$ & $\$ 1,507$ \\
Grower 12 & $\$ 5,787$ & $\$ 487$ & $\$ 1,372$ \\
Grower/packhouse 1 & $\$ 6,501$ & $\$ 520$ & $\$ 1,494$ \\
Grower 11 & $\$ 6,720$ & $\$ 538$ & $\$ 1,622$ \\
Grower/packer 1 & $\$ 7,421$ & $\$ 594$ & $\$ 1,631$ \\
Grower 4 & $\$ 6,328$ & $\$ 506$ & $\$ 1,454$ \\
Grower 3 & $\$ 7,835$ & $\$ 627$ & $\$ 1,932$ \\
Grower 6 & $\$ 8,918$ & $\$ 660$ & $\$ 1,996$ \\
Grower 5 & $\$ 8,887$ & $\$ 684$ & $\$ 1,991$ \\
Grower 2 & $\$ 10,865$ & $\$ 808$ & $\$ 2,362$ \\
Grower 10 & $\$ 11,988$ & $\$ 959$ & $\$ 2,616$ \\
Contractor 1 & $\$ 9,638$ & $\$ 771$ & $\$ 2,184$ \\
Grower 13 & $\$ 11,005$ & $\$ 922$ & $\$ 2,602$ \\
Grower 9 & $\$ 11,253$ & $\$ 900$ & $\$ 2,494$ \\
Cooperative 1 & $\$ 15,278$ & $\$ 1,226$ & $\$ 3,506$ \\
Grower 1 & $\$ 15,377$ & $\$ 1,141$ & $\$ 3,109$ \\
Grower 7 & $\$ 17,398$ & $\$ 1,333$ & $\$ 3,532$ \\
Un-weighted AVERAGE & $\$ 9,893$ & $\$ 778$ & $\$ 2,200$ \\
\hline Weighted AVERAGE & $\$ 10,755$ & $\$ 849$ & $\$ 2,392$ \\
\hline
\end{tabular}


The average gross pay showed a wide range from over $\$ 5,787$ to $\$ 17,398$ while the weighted average across all employer types was $\$ 10,755$. Holiday pay and PAYE varied in line with this distribution.

\section{Table 4: Average balance or net returns for workers}

\begin{tabular}{lc}
\hline RSE type & AVG Net returns \\
\hline Grower 8 & $\$ 2,871$ \\
Grower 12 & $\$ 3,008$ \\
Grower/packhouse 1 & $\$ 3,359$ \\
Grower 11 & $\$ 3,658$ \\
Grower/packer 1 & $\$ 3,738$ \\
Grower 4 & $\$ 3,774$ \\
Grower 3 & $\$ 4,204$ \\
Grower 6 & $\$ 4,299$ \\
Grower 5 & $\$ 4,739$ \\
Grower 2 & $\$ 5,466$ \\
Grower 10 & $\$ 5,881$ \\
Contractor 1 & $\$ 6,054$ \\
Grower 13 & $\$ 6,217$ \\
Grower 9 & $\$ 6,265$ \\
Cooperative 1 & $\$ 7,843$ \\
Grower 1 & $\$ 8,710$ \\
Grower 7 & $\$ 11,864$ \\
Un-weighted AVERAGE & $\$ 5,409$ \\
\hline Weighted AVERAGE & $\$ 5,950$ \\
\hline
\end{tabular}

As indicated earlier the Average balance or net returns was derived taking away the taxes, deductions and costs from gross pay earned. The net returns showed considerable variation from $\$ 2,871$ to $\$ 11,864$, which gives a range that a worker might expect to earn after taxes and deductions. The weighted average was $\$ 5950$. The first iteration of this audit comprising 12 RSE employers had placed the un-weighted average net returns at $\$ 5,765$.

From the data provided above, it would appear that workers averaged 36 hours per week and earned around $\$ 16$ per hour. This would indicate that the minimum requirement of the policy in terms of weekly hours and hourly rates are being met on average.

\section{Part 2 - Analysis of individual worker returns}

This analysis based on individual records shows a better picture of the distribution of net returns. As table 4 below shows there is reasonable variation even within individual RSE employers. For instance Cooperative 1 shows a minimum of $\$ 1,704$ and a maximum of $\$ 10,173$. Clearly the range varies more with the increase in number of workers within a RSE.A further analysis of the distribution across the overall group of 402 workers was undertaken.

This analysis shows as in table 5 below that the lower quarter of workers observed earnings were at $\$ 3,707$ and below and the upper quarter at $\$ 7,779$ and below and the median was $\$ 5.625$.
Table 5: Worker net returns across different RSEs

\begin{tabular}{lcccc}
\hline RSE type & Mean & Min & Max & N \\
\hline Contractor 1 & $\$ 6,054$ & $\$ 3,568$ & $\$ 10,161$ & 19 \\
Cooperative 1 & $\$ 7,843$ & $\$ 1,704$ & $\$ 10,173$ & 50 \\
Grower 1 & $\$ 8,710$ & $\$ 3,123$ & $\$ 11,383$ & 20 \\
Grower 10 & $\$ 5,881$ & $\$ 3,752$ & $\$ 16,413$ & 30 \\
Grower 11 & $\$ 3,658$ & $\$ 2,023$ & $\$ 5,142$ & 23 \\
Grower 12 & $\$ 3,008$ & $\$ 1,718$ & $\$ 4,038$ & 22 \\
Grower 13 & $\$ 6,217$ & $\$ 2,288$ & $\$ 7,213$ & 30 \\
Grower 2 & $\$ 7,724$ & $\$ 3,525$ & $\$ 10,334$ & 23 \\
Grower 3 & $\$ 4,204$ & $\$ 2,764$ & $\$ 6,698$ & 22 \\
Grower 4 & $\$ 3,774$ & $\$ 2,690$ & $\$ 5,898$ & 22 \\
Grower 5 & $\$ 4,739$ & $\$ 3,652$ & $\$ 5,715$ & 15 \\
Grower 6 & $\$ 4,299$ & $\$ 3,567$ & $\$ 5,735$ & 15 \\
Grower 7 & $\$ 11,864$ & $\$ 3,666$ & $\$ 14,511$ & 35 \\
Grower 8 & $\$ 2,871$ & $\$ 2,364$ & $\$ 3,387$ & 10 \\
Grower 9 & $\$ 6,265$ & $\$ 4,033$ & $\$ 9,134$ & 30 \\
Grower-packer 1 & $\$ 3,738$ & $\$ 3,277$ & $\$ 4,390$ & 20 \\
Grower/packhouse 1 & $\$ 3,359$ & $\$ 2,419$ & $\$ 3,665$ & 16 \\
\hline
\end{tabular}

Table 6: Quantiles for $\log$ normal distribution

\begin{tabular}{ccc}
\hline Percent & Observed & Estimated \\
\hline 1 & $\$ 2,238$ & $\$ 2,095$ \\
5 & $\$ 2,774$ & $\$ 2,676$ \\
10 & $\$ 3,180$ & $\$ 3,086$ \\
25 & $\$ 3,707$ & $\$ 3,978$ \\
50 & $\$ 5,625$ & $\$ 5,382$ \\
75 & $\$ 7,779$ & $\$ 7,406$ \\
90 & $\$ 10,173$ & $\$ 9,981$ \\
95 & $\$ 12,018$ & $\$ 11,980$ \\
99 & $\$ 13,057$ & $\$ 16,976$ \\
\hline
\end{tabular}

The average net return of $\$ 6,079$ is quite close to the weighted average net return of $\$ 5,950$ referred to in Table 1. A standard deviation of $\$ 2,813$ around the average net return means that two-thirds $(68 \%)$ of the workers were able to obtain a net return ranging between $\$ 3,266$ and $\$ 8,892$.

How does this snapshot compare to other information on income and savings?

Earlier in 2008 the Internal Revenue Department (IRD) had provided an analysis of gross incomes earned by RSE workers. IRD undertook an analysis of RSE workers' gross income in order to develop an RSE tax code (to avoid the need for tax rebates or refunds for RSE workers who were ordinarily placed on the general income tax code). IRD took the average weekly earning by country for RSE workers from two RSE employers: one large employer with workers from Samoa, Tonga, Tuvalu and Vanuatu and another with workers from Kiribati for the week ending 30 April 2008. IRD noted that some RSE workers had worked for longer periods and were more experienced. The IRD indicative findings are summarised in the table below.

Table 7: IRD estimates of gross earnings for a limited sample of RSE workers

\begin{tabular}{lcccc}
\hline Country & High & Low & Average & $\begin{array}{c}\text { No of weeks } \\
\text { worked }\end{array}$ \\
\hline Kiribati & $\$ 900.00$ & $\$ 600.00$ & $\$ 680.00$ & 14 \\
Samoa & $\$ 624.00$ & $\$ 443.66$ & $\$ 545.21$ & 5 \\
Tonga & $\$ 660.56$ & $\$ 361.39$ & $\$ 556.57$ & 3 \\
Vanuatu & $\$ 621.62$ & $\$ 495.55$ & $\$ 418.65$ & 2 \\
Tuvalu & $\$ 612.84$ & $\$ 258.47$ & $\$ 403.93$ & 7 \\
\hline
\end{tabular}

Source: IRD presentation, KSS Forum 2008 


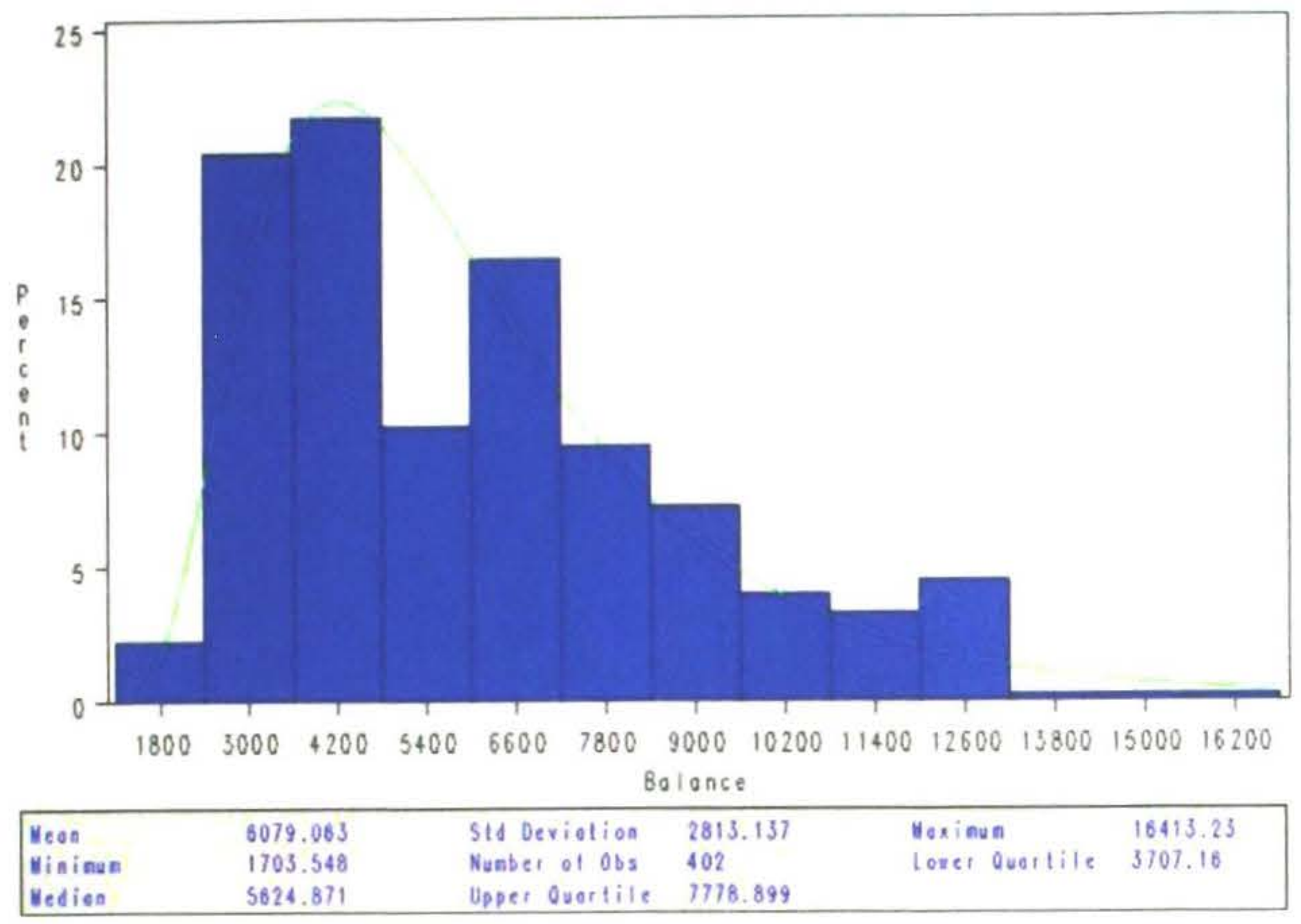

IRD's analysis shows that for week ending 30 April 2008, workers in the sample who were from Kiribati were earning significantly more than those from other countries and workers from Tuvalu earned the least. The IRD's information about the gross earnings for workers from Kiribati and Tuvalu is generally in line with data about the range of gross earnings of the 402 workers that were included in the audit. In the absence of more detailed information, it seems reasonable to assume that the findings from the audit about earnings and net income also apply in general to workers from Kiribati and Tuvalu, except for the additional travel costs.

A major study by the World Bank (Luthria et al 2006), which informed the development of the RSE policy, had undertaken a modeling of savings potential for seasonal workers. This work modeled wages, costs, tax obligations, and savings potential of Pacific Island employed in horticultural jobs in Australia for periods of up to six months at a time to assess whether a scheme is potentially viable for both growers and migrant workers.

Table 8: Summary of savings potential for off-shore seasonal workers

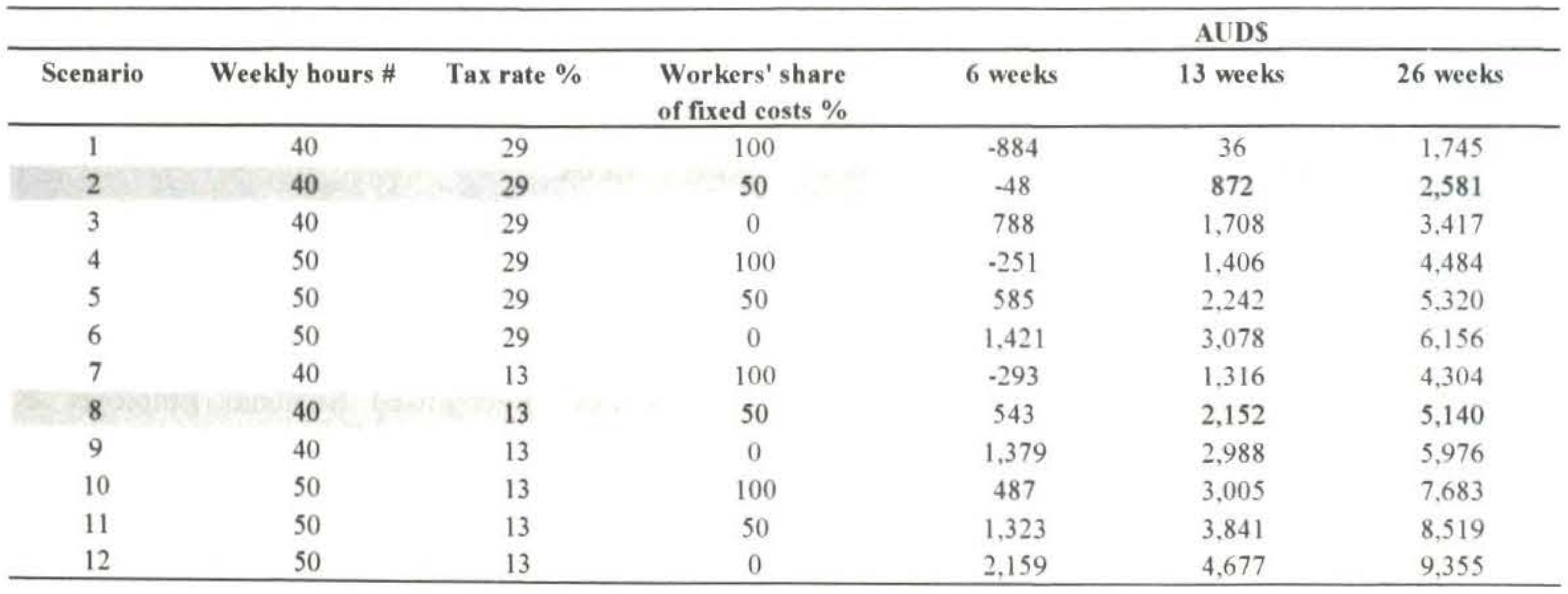

Source: Luthria et al, 2006

The above table is a summary of the savings potential of Pacific Islander workers using different assumptions for taxation, cost sharing, and working hours. Further this does not include upfront or ongoing living costs as covered in the New Zealand audit and therefore not comparable. However scenarios 2 and 8 have assumptions somewhat similar to the New Zealand scenario in terms of $50 \%$ employer paid airfare and 40 weeks of work. The main difference between scenarios 2 and 8 is the tax rates of $29 \%$ and $13 \%$. A crude midpoint 
between both these scenarios provides a potential savings of A\$ 2348 or NZ\$ 2,730 (at 0.86 exchange rate). Once additional costs are factored this net return would drop further. This seems to indicate that these modeling estimates may have been conservative.

The DoL as part of its internal workings at the time of the RSE policy development attempted estimating savings after tax and costs (accommodation, food, transport and $50 \%$ airfare) earnings for 3 months at 60 hours per week. These workings covered a range of kick start states and both horticulture and viticulture industries. The estimates ranged from around $\$ 4500$ to $\$ 5500$ and appear plausible in the light of the audit findings.

\section{Conclusions}

The audit data indicates that the average weekly hours and hourly rates are above the minimum prescribed in the policy. Further the indicative evidence that on average workers make net returns of around $\$ 6000$ is some assurance that workers do economically gain from the RSE policy. It is also clear that for many workers their potential savings will fall below this average figure and that we do not have a complete picture of all costs.

The calculation of net returns is not a simple exercise. As indicated earlier besides worker characteristics the circumstances and factors that determine worker incomes can and do vary among crops, tasks and regions and across both horticulture and viticulture industries. Further the ability to make a net return is not guaranteed as reflected through issues around insufficient hours of work at times among some employers. Such problems may indicate employers' lack of experience with RSE policy and the demands of managing in new circumstances with greater responsibilities. Seasonal variations and weather volatility may further exacerbate the problems.

This makes it all the more significant to obtain reliable estimates of net earnings where possible. The audit exercise provides one avenue for collecting such data notwithstanding the limitations. Even surveys may not yield accurate estimates given the issues around misunderstandings around deductions and poor recall of money transactions apart from logistical difficulties in administering such a survey among seasonal workers.

Ideally an audit covering winter months would help assemble a more rounded picture of net earnings for workers. The current estimates as indicated earlier covered the months when the weather and work availability was relatively more settled. The key missing information however would continue to be the additional costs of living that workers incur on a weekly basis. The survey based evaluation of development outcomes by the Waikato University and World Bank may help flesh out the picture of net earnings further. Besides this evaluation will also help answer the counterfactual question of what workers may have earned in the absence of the RSE policy. It is also possible that when a RSE tax code is implemented by the IRD then better estimates of gross and post-tax earnings could be analysed from the Linked Employer Employee Data.

\section{Notes}

1. RSE policy involves a four step process: employers gain accreditation and RSE status, employers lodge an ATR to recruit specific number of employees, workers lodge visa application and workers are deemed eligible to return the following season subject to conditions being met.

2. Apart from dedicated immigration compliance staff, there are six RSE labour inspectors across the regions including a coordinator based in Wellington.

3. http://www.islandsbusiness.com/islands_business/i ndex_dynamic/containerNameToReplace $=$ Middle Middle/focusModuleID=18141/overideSkinName =issueArticle-full.tpl

4. Evaluation objectives aim at describing and assessing implementation, management of risks and short-term outcomes.

5. International Migration, Settlement and Employment Dynamics Research is a part of the Workforce Policy Group, DoL.

6. Fiji was dropped from this group of Pacific states following the 2006 coup in that country.

7. Based on the predominant business activity, RSE employers are classified by the following types: Growers, Contractors, Cooperatives, Grower/packhouse and Grower/packer.

8. Of the 17 , only 6 had actual deductions and in the case of the balance the figure of $\$ 41$ was imputed based on phase 1 audit.

\section{References}

Courtney, C. (2008). 'Growing pains', North \& South, April 2008:70-9.

Government of New Zealand (2006) Temporary Work Policy: Recognised Seasonal Employer Policy, POL (06) 311, 17 October 2006, Cabinet Policy Committee, Wellington.

Hammond, J. and Connell, J. (2008) The new blackbirds? Vanuatu guestworkers in New Zealand, Unpublished manuscript.

Luthria, M., Duncan, R., Brown, R., Mares, P., Maclellan, N., with Booth, H. (2006) Expanding Job Opportunities for Pacific Islanders through Labour Mobility at Home and Away, The World Bank, Washington, DC. 
Ramasamy, S., Krishnan, V., Bedford, R. and Bedford,C. (2008) "The Recognised Seasonal Employer policy: seeking the elusive triple wins for development through international migration" Pacific Economic Bulletin 23(3):171-186.

Maclellan, N. (2008) Workers for all Seasons? Issues from New Zealand's Recognised Seasonal Employer (RSE) Program, Institute for Social Research, Swinburne University of Technology, Hawthorn, Australia.

\section{Author}

Sankar Ramasamy

Principal Analyst

IMSED Research

Department of Labour

PO Box 3705

Wellington

Sankar.Ramasamy@dol.govt.nz

\section{Appendix A}

Holidays Act 2003 ensures all workers access standard entitlements. Under the RSE policy it is recommended that holiday pay is paid at $8 \%$ of their total gross earnings on termination of their employment. This will ensure that they have money to take back home once their employment is terminated.

As per the Employment Relations Act 2000 an individual employment agreement must be in writing and should include a description of the work, indication of where the employee is to work and an indication of arrangements relating to working hours. It is recommended that RSE employees should be given a fixed term employment agreement.

The Minimum Wage Act 1983 provides a statutory wages floor by fixing minimum rates across the board in all employment. Workers under the RSE policy should not be paid less than the market rate for the actual hours worked and where piece rates apply the piece rates should be specified which must be consistent with the typical rate a New Zealand citizen or resident worker is paid for the equivalent work in the same period and region.

The Wages Protection Act 1983 sets out a number of fundamental rules relating to the payment of wages. Perhaps the most significant is that no deductions can be made from wages except in accordance with the Act. The RSE policy states that any deductions made, including deductions for accommodation, must not take a workers weekly pay below minimum wage except where an employer has advanced payment to a worker to cover up to half the return travel cost.

\section{Appendix B}

Table 9: Identified and achieved sample

\begin{tabular}{|c|c|c|c|c|c|}
\hline Region & Employer & Period of Employment & $\begin{array}{c}\text { Identified } \\
\text { sample }\end{array}$ & $\begin{array}{c}\text { No of named } \\
\text { records }\end{array}$ & $\begin{array}{c}\text { Achieved } \\
\text { sample }\end{array}$ \\
\hline \multirow[t]{2}{*}{ Bay of Plenty } & Grower/packhouse 1 & $31 / 03 / 2008 \sim 20 / 06 / 2008$ & 40 & 15 & 16 \\
\hline & Grower 8 & $11 / 05 / 2008 \sim 15 / 06 / 2008$ & 15 & 15 & 10 \\
\hline Canterbury & Grower/packer 1 & $18 / 02 / 2008 \sim 24 / 05 / 2008$ & 20 & 20 & 20 \\
\hline \multirow[t]{7}{*}{ Hawkes Bay } & Grower 12 & $18 / 02 / 2008 \sim 16 / 05 / 2008$ & 22 & 22 & 22 \\
\hline & Grower 5 & $07 / 01 / 2008 \sim 25 / 04 / 2008$ & 35 & 38 & 15 \\
\hline & Grower 10 & $19 / 11 / 2007 \sim 19 / 06 / 2008$ & 30 & 30 & 30 \\
\hline & Contractor 1 & $01 / 12 / 2007 \sim 31 / 05 / 2008$ & 20 & 19 & 19 \\
\hline & Grower 11 & $25 / 02 / 2008 \sim 30 / 04 / 2008$ & 20 & 23 & 23 \\
\hline & Grower 9 & $19 / 11 / 2007 \sim 31 / 05 / 2008$ & 50 & 51 & 30 \\
\hline & Grower 13 & $25 / 11 / 2007 \sim 30 / 04 / 2008$ & 30 & 30 & 30 \\
\hline Manuwatu & Grower 2 & $20 / 09 / 2007 \sim 23 / 12 / 2007$ & 23 & 23 & 23 \\
\hline Marlborough & Contractor 2 & $03 / 12 / 2007 \sim 25 / 04 / 2008$ & 30 & 22 & 0 \\
\hline \multirow[t]{4}{*}{ Nelson } & Grower 6 & $18 / 02 / 2008 \sim 29 / 05 / 2008$ & 20 & 16 & 15 \\
\hline & Grower 4 & $18 / 02 / 2008 \sim 05 / 05 / 2008$ & 30 & 22 & 22 \\
\hline & Grower 3 & $18 / 02 / 2008 \sim 05 / 05 / 2008$ & 25 & 22 & 22 \\
\hline & Grower 7 & $01 / 11 / 2007 \sim 01 / 06 / 2008$ & 35 & 35 & 35 \\
\hline Northland & Grower 1 & $10 / 09 / 2007 \sim 10 / 04 / 2008$ & 20 & 20 & 20 \\
\hline Otago & Cooperative 1 & $22 / 10 / 2007 \sim 19 / 05 / 2008$ & 232 & 229 & 50 \\
\hline Total $=8$ & 18 & & 697 & 652 & 402 \\
\hline
\end{tabular}

